Jurdimas (Jurnal Pengabdian Kepada Masyarakat) Royal

Vol. 2 No. 2, Juli 2019, hlm. 93 - 100

ISSN 2614-7912 (Print)

DOI: https://doi.org/10.33330/jurdimas.v2i2.275

ISSN 2622-3813 (Online)

Available online at https://jurnal.stmikroyal.ac.id/index.php/jurdimas

\title{
PELATIHAN PUBLIC SPEAKING BERBASIS TEKNOLOGI INFORMASI DI KELURAHAN JOHAR BARU
}

\author{
Dini Safitri \\ Fakultas Ilmu Sosial, Universitas Negeri Jakarta \\ Email: dinisafitri@unj.ac.id
}

\begin{abstract}
This community service aims to empower people who are members of the Yasayan Senyum Ibu Indonesia (YSII), so that they dare to appear to do public speaking. Empowerment needs to be done, considering the number of Foundation activities that require public speaking skills. The empowerment method used in this service has three stages. The first stage is to introduce and teach participants, how to find material or material to be delivered in public speaking, using the internet. After the material is obtained, they are asked to arrange the sentences that will be delivered in public speaking, then practice them one by one. The second method is to teach and practice the participants to hear a lot while memorizing the words that have been heard, to be memorized and repeated. This method is the basic method of public speaking, which relies a lot on memory, based on what is heard, then memorized. After memorizing, recited in public speaking activities. The third method is one by one the participants learn to recite flat voice intonation, as a basic technique in public speaking. The results of this service are public speaking modules that will be made HKI, popular articles in online media, and scientific articles in public service journals.
\end{abstract}

Keywords: Public Speaking, Internet, Information Technology

\begin{abstract}
Abstrak: Pengabdian ini bertujuan untuk memberdayakan masyarakat yang tergabung dalam Yasayan Senyum Ibu Indonesia (YSII), agar berani tampil untuk melakukan public speaking. Pemberdayaan ini perlu dilakukan, mengingat banyaknya kegiatan Yayasan yang memerlukan keterampilan public speaking. Metode pemberdayaan yang digunakan dalam pengabdian ini ada tiga tahap. Tahap pertama, adalah mengenalkan dan mengajarkan kepada para peserta, cara mencari bahan atau materi yang akan disampaikan dalam public speaking, dengan menggunakan internet. Setelah bahan di dapatkan, mereka diminta untuk menyusun kalimat yang akan disampaikan di dalam public speaking, kemudian mempraktikannya satu-persatu. Metode kedua adalah mengajarkan dan mempraktikan kepada para peserta untuk banyak mendengar sekaligus menghafalkan kata-kata yang telah didengar, untuk dihapalkan dan diulang kembali. Metode ini adalah metode dasar public speaking, yang banyak mengandalkan daya ingat, berdasarkan dari apa yang didengar, kemudian dihapalkan. Setelah hapal, dilafalkan dalam kegiatan public speaking. Metode ketiga adalah satu persatu peserta belajar melafalkan intonasi suara datar, sebagai teknik dasar dalam public speaking. Hasil dari kegiatan pengabdian ini adalah modul public speaking yang akan dibuat HKI, artikel popular di media online, adan artikel ilmiah di jurnal pengadian masyarakat.
\end{abstract}

Kata Kunci: Public Speaking, Internet, Teknologi informasi 
Jurdimas (Jurnal Pengabdian Kepada Masyarakat) Royal

Vol. 2 No. 2, Juli 2019, hlm. 93 - 100

ISSN 2614-7912 (Print)

DOI: https://doi.org/10.33330/jurdimas.v2i2.275

ISSN 2622-3813 (Online)

Available online at https://jurnal.stmikroyal.ac.id/index.php/jurdimas

\section{PENDAHULUAN}

Yayasan Senyum Ibu Indonesia (YSII) adalah sebuah yayasan sosial, kemanusiaan dan keagamaan, yang memiliki tujuan untuk meningkatkan potensi wanita menuju kehidupan yang lebih baik khususnya di bidang kesehatan dan pendidikan. YSII didirikan dengan tiga maksud, yaitu untuk memberikan pelayanan pendidikan dan kesehatan sebagai bagian dari peningkatan kualitas sember daya manusia, meningkatkan pengetahuan dan wawasan wanita sebagai pencetak generasi bangsa, dan melakukan pembinaan serta pemberdayaan wanita untuk meningkatkan kualitas keluarga dan masyarakat.

Sayangnya dengan tujuan dan maksud yang sudah disebutkan diatas, YSII hanya memiliki sasaran program kerja yang terbatas, yaitu masyarakat wanita dan anak-anak Indonesia yang berdomisili di Jabodetabek khususnya di Kecamatan johar Baru Jakarta Pusat. Padahal organisasi ini sudah berdiri sejak Maret 2008, dan mulai aktif mempublikasikan nama Yayasan Senyum Ibu Indonesia pada acara Launching tanggal 26 Juli 2009. Selain itu, YSII juga memiliki ruang lingkup kegiatan yang cukup luas, yaitu terdiri dari empat bidang. Pertama Bidang pendidikan. Kedua Bidang Kesehatan. Ketiga, Bidang Pengembangan Dana dan Ekonomi. Dan keempat Bidang Humas.

YSII memiliki Akta Pendirian Nomor 6. tanggal 6 Agustus 2009, dengan Notaris Andi Gustar, S.H. Dan juga memiliki Akta Perubahan Nomor 13. Tanggal 14 Agustus 2012. YSII secara kelembagaan juga sudah terdaftar di Kementrian Hukum dan Ham dengan
Nomor AHU-2798.AH.01.04 tahun 2009. Tak hanya itu, YSII juga telah memiliki tanda Daftar Yayasan/badan Sosial dari Dinas Sosial Provinsi DKI Jakarta dengan nomor 013.31.71.08.1001.45 B. Dan juga telah memiliki NPWP dengan nomor 02.836.659.9-024.000.

YSII beralamat di Jln. Johar Baru Utara III RT 010/04 No. 13 Kel. Johar Baru Jakarta Pusat 10560 dan memiliki Surat Domisili Yayasan dari Kelurahan Johar Baru. YSII juga memiliki rekening di Bank DKI Syariah cabang Wahid Hasyim nomor 7017220115 atas nama Yayasan Senyum Ibu Indonesia. Untuk nomor kantor, dapat di hubungi di 021$\begin{array}{llll}422 & 69 & 22 & \text { dan alamat surel }\end{array}$ senyumibuindonesia@gmail.com.

Sebagai organisasi yang sudah cukup lama berdiri, telah banyak program yang dilakukan YSII, antara lain adalah Seminar parenting, Pelatihan Daur Ulang, Lomba untuk anak (mewarnai, melukis, mengarang, dan membaca puisi), Lomba untuk ibu (kompetisi esay dan kreasi hijab), seminar kesehatan, bedah buku, talkshow Pendidikan, penyuluhan, dan mengelola taman baca. Berikut ini, foto kegiatan sebagian kecil dari kegiatan YSII:

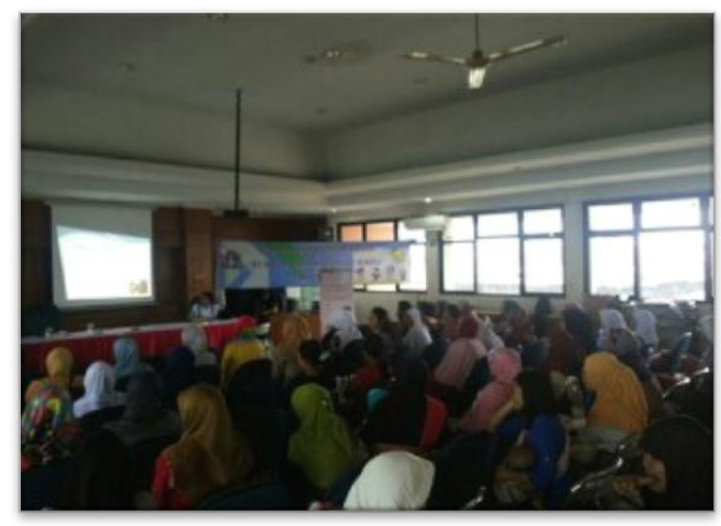

Gambar 1. Foto Kegiatan 


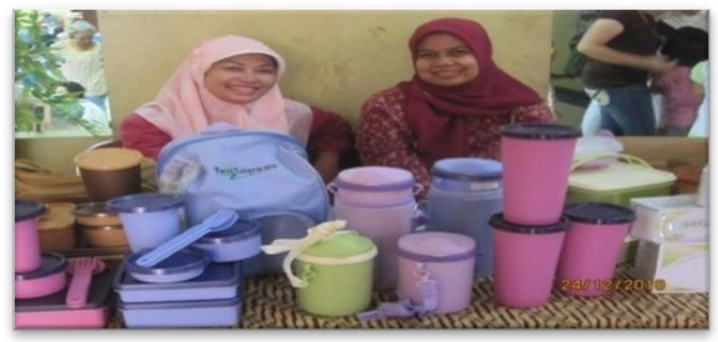

Gambar 2. Foto Kegiatan

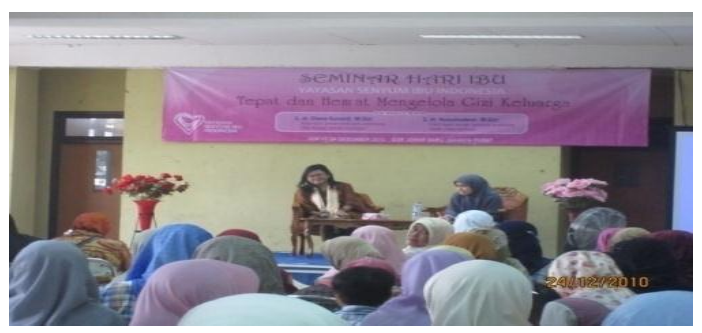

Gambar 3. Foto Kegiatan

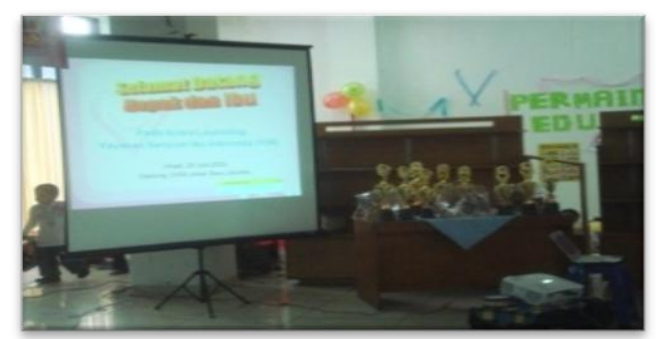

Gambar 4. Foto Kegiatan

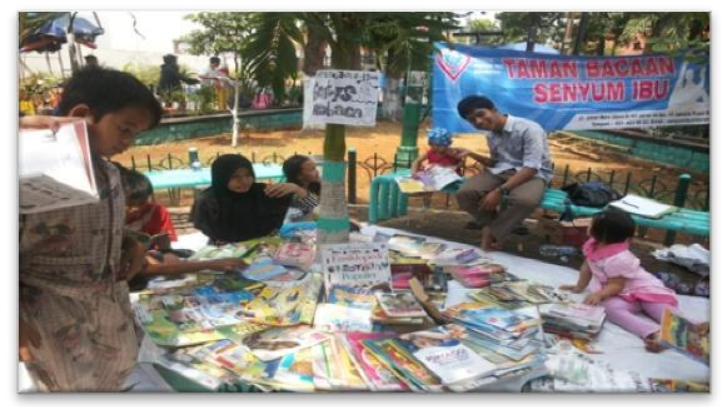

Gambar 5. Foto Kegiatan

Melalui foto-foto di atas, kita dapat melihat bagaimana program nyata YSII. Namun sayangnya, belum banyak pengurus YSII yang tampil aktif untuk melakukan public speaking di masyarakat, sehingga program kerja YSII belum dapat tersosialisasi secara nasional. Oleh karena itu, melalui program PkM, kami akan memberikan sejumlah training dan konsultasi yang bertujuan untuk meningkatkan kemampuan public speaking untuk YSII, sekaligus mengajarkan kepada mereka untuk mencari dan membuat sendiri bahan atau materi public speaking dari internet. Hal tersebut, merupakan kegiatan penting untuk memberdayakan sumber daya manusia di YSII, karena bayaknya ketersediaan informasi yang bisa didapatkan berbasis tekonologi informasi, sehingga program YSII bisa diterima secara luas dan menigkat pada skala nasional.

Kehadiran media sosial telah dirasakan sebagai sarana yang dapat dimanfaatkan untuk mempermudah urusan manusia. Diantaranya, dapat digunakan untuk menjaga soliditas, merubah opini, mengobarkan semangat, dan pencatat sejarah. Oleh Karena itu, dengan memanfaatkan karakteristik media sosial, para pengelola yayasan, seharusnya lebih mampu untuk memanfaatkan kehadiran media sosial untuk mengonstruksi pesan positif mengenai program kerja yayasan.

Kecenderungan kehidupan masyarakat saat ini, yang tidak dapat jauh dari gadget, menjadikan media sosial sudah menjadi bagian penting dari penyebaran informasi di Indonesia selama beberapa tahun terakhir. Berdasarkan penelusuran Hearne, Jakarta adalah ibukota twitter sedunia. Setiap hari 2,4 persen tweet dunia berasal dari Indonesia, artinya 1 tweet dikirim tiap 15 detik. Oleh Karena itu, tidak mengherankan bila persoalan Indonesia yang menjadi viral di media sosial, juga menjadi perbincangan global 
Jurdimas (Jurnal Pengabdian Kepada Masyarakat) Royal

Vol. 2 No. 2, Juli 2019, hlm. 93 - 100

ISSN 2614-7912 (Print)

DOI: https://doi.org/10.33330/jurdimas.v2i2.275

ISSN 2622-3813 (Online)

Available online at https://jurnal.stmikroyal.ac.id/index.php/jurdimas

di seluruh dunia. Potensi tersebut, sepatutnya dapat dikelola dengan baik dalam pengelolaan isu strategis nasional, agar warga Indonesia dapat terlibat dalam mengampanyekan berbagai program, terutama yang bertujuan untuk memberdayakan dan mensejahterakan kehidupan bangsa.

Namun sayangnya, belum banyak yayasan yang berkecimpung dalam bidang sosial kemasyarakatan memahami betul manfaat dari kehadiran media sosial. Hal tersebut salah satunya dikarenakan, kurangnya kompetensi dari sumber daya manusia di dalam yayasan untuk mengoperasikan media sosial sebagai tempat menyebarluaskan informasi dan nilai-nilai sosial di masyarakat. Karena kurangnya kompetensi tersebut, maka kegiatan yayasan yang positif, kurang mendapat dukungan penuh dari masyarakat luas. Apalagi sampai dapat menjadi rujukan warga, minimal untuk menjadi trainer atau tempat konsultasi yang terkait dengan pembangunan karakter ibu jaman ini.

Paparan masalah singkat di atas, juga dialami oleh YSII. YSII sudah cukup lama berdiri, yaitu sudah 10 tahun, tepatnya pada bulan maret 2008. Dan sudah banyak kegiatan yang dilakukannya untuk mencapai tujuan yayasan. Namun sayangnya, belum banyak masyarakat yang tahu mengenai nama yayasan ini, begitu pula dengan program kerjanya. Oleh karena itu, melalui program $\mathrm{PkM}$, kami akan memberikan sejumlah training dan konsultasi yang bertujuan untuk meningkatkan ketersediaan informasi yang lebih luas mengenai YSII dan menigkatkan kompetensi sumber daya manusia didalamnya, melalui training dan konsultasi public speaking berbasis teknologi informasi.

\section{METODE}

Ada lima tahap pelaksanaan yang akan dilakukan dalam PkM ini, yaitu dari mulai tahap pendekatan, tahap persiapan, tahap pelaksanaan, tahap pelatihan, dan sampai ada tahap evaluasi. Di bawah ini akan dipaparkan secara singkat apa saja metode yang akan dilakukan pada masing-masing tahap tersebut.

\section{Metode Pendekatan}

Sebelum memulai pembuatan proposal pengabdian, terlebih dahulu dilakukan metode pendekatan terhadap mitra sasaran. Hal tersebut dilakukan agar dapat dicari tahu permasalahan yang mereka hadapi, sehingga dapat dicari solusi dengan memperhatikan keterlibatan mitra secara pro aktif. Ada tiga hal yang dilakukan dalam metode pendekatan. Pertama, mendiskusikan permasalahan bersama mitra, yaitu pengurus inti YSII. Kedua, merancang solusi permasalah bersama tim PkM. Ketiga, dibuat desain pelaksanaan program.

\section{Persiapan Pelaksanaan Program}

Sebelum masuk pada tahap pelaksanaan, terlebih dahulu dilakukan sosialisasi terhadap mitra terkait, dalam hal ini YSII. Di dalam sosialisasi, beberapa pihak terkait dari YSII, dari mulai Pembina, Pengawas, Pengurus Inti, Pengurus dan Perwakilan dari anggota komunitas dihadirkan. Dengan adanya acara sosialisasi tersebut, diharapkan semua pihak terkait, akan mendukung 
Jurdimas (Jurnal Pengabdian Kepada Masyarakat) Royal

Vol. 2 No. 2, Juli 2019, hlm. 93 - 100

ISSN 2614-7912 (Print)

DOI: https://doi.org/10.33330/jurdimas.v2i2.275

ISSN 2622-3813 (Online)

Available online at https://jurnal.stmikroyal.ac.id/index.php/jurdimas

sepenuhnya program ini baik secara kelembagaan, materiil, dan moril.

\section{Tahap Pelaksanaan}

Untuk meningkatkan solusi terhadap permasalahan mitra, sebagaimana yang direncanakan, maka pada tahapan ini, disusun kegiatan atau program $\mathrm{PkM}$ publik speaking berbasis teknologi informasi. Ada tiga tahap dalam pelaksanaan, yaitu dimulai dari mengajarkan mencari bahan materi public speaking di internet, sampai menyusun materi public speaking. Tahap kedua adalah melafalkan secara berulang teks materi public speaking. Tahap ketiga adalah berani tampil membawakan materi public speaking yang sudah disusun dan dicari sendiri oleh masing-masing peserta.

\section{Pelatihan}

Untuk meningkatkan kemapuan SDM YSII dalam membuat materi dan melakukan public speaking, disusun materi pelatihan yang akan dilaksanakan. Adapun susunannya adalah dari mulai perkenalan pemateri, penyampaian materi, praktik mencari bahan materi public speaking, praktik pembutan materi public speaking dan tampil membawakan materi public speaking secara satu persatu.

\section{Evaluasi}

Tahap terakhir dan paling penting dalam setiap program adalah Evaluasi. Evaluasi yang baik dilaksanakan secara keseluruhan. Kegiatan evaluasi bertujuan untuk mendapatkan umpan balik, sebagai bahan acuan dan tolak ukur untuk menjamin keberlangsungan sebuah program di masa yang akan datang. Adapun metode evaluasi dalam $\mathrm{PkM}$ ini adalah dengan membuat testimoni di selembar kertas yang telah dibagikan. Serta disediakan form evaluasi.

\section{PEMBAHASAN}

Kegiatan PKM yang mengambil tema pubic speaking ini, dilaksanakan pada Yasayan Senyum Ibu Indoenesia. Kegiatan ini diselenggatakan pada tanggal 30 September 2018, bertempat di aula kantor kelurahan Johar Baru. Terdapat 24 peserta yang mengikuti kegiatan ini. Kegiatan PKM public speaking ini berbasis teknologi informasi. Kegiatan ini bertujuan untuk memberdayakan para peserta dari YSII untuk dapat membuat materi public speakingnya sendiri dengan menggunakan internet. Setelah peserta mendapatkan bahan untuk materi public speaking, mereka kemudian menyusun dan menrancang materi mereka sendiri. Kemudian mereka berlatih menghapalkan, dengan cara banyak mendengar suara mereka sendiri dan mengulang-ulang hapalan mereka. Setelah dirasakan cukup, para peserta dipersilahkan tampil satu persatu.

Kegiatan PKM Public Spaeking ini menggunakan elemen wacana pedagogi yang dikemukakan oleh Basil Bernstein. Menurut Bernstein, wacana pedagogi terdiri dari kelas, kode dan kontrol. Namun dalam kegiatan pengabdian ini, tim pengabdian mengembangkan metode sendiri, menjadi wacana kelas pedagogi public speaking.

Masih mengacu pada teori Bernstein, wacana kelas pedagogi public speaking ini dibuat di dalam ruang atau kelas yang dikendalikan oleh tim 
Jurdimas (Jurnal Pengabdian Kepada Masyarakat) Royal

Vol. 2 No. 2, Juli 2019, hlm. 93 - 100

DOI: https://doi.org/10.33330/jurdimas.v2i2.275

ISSN 2614-7912 (Print)

Available online at https://jurnal.stmikroyal.ac.id/index.php/jurdimas

pengabdian dan peserta sendiri. Hanya saja, peserta lebih banyak menentukan dan aktif mencari bahan materi untuk public speaking yang akan disampaikan. Sementara tugas dari tim pengabdian hanya sebagai fasilitator dan konsultan yang mengarahkan keinginan dari materi yang peserta usulkan. Proses untuk menggagas ide, menyusun eksplikasi dan membuat perangkat materi, sehingga gagasan ide tersebut dapat dimengerti, dan dimaknai, sepenuhnya dikendalikan oleh masing-masing peserta. Setelah ide tersebut disepakati antara masing-masing peserta dengan pemateri, maka bahan untuk materi public speaking, mulai disusun peserta dan dikoreksi bersama oleh pemateri.

Setelah itu, peserta diberikan waktu untuk melafalkan, dan banyak mengulang-ulang materi public speaking yang akan dipraktekan. Proses pelafalan dan mengulang ini, bertujuan merangsang daya dengar dan daya ingat para peserta pengabdian ini. Setelah dirasakan cukup, mata satu persatu peserta dipersilahkan tampil untuk public speaking.

Dalam melakukan penerusan ide dan bahan, para peserta diarahkan untuk menyusun materi yang mudah dimengerti dan diterima oleh masyarakat pada umumnya. Dan pada saat praktik, diharapkan, tersedia video untuk merekam kegiatan. Kemudian hasil video pelatihan ini dapat disebarkan melalui jaringan komunikasi dalam Yayasan. Namun sayangnya kegiatan perekaman dan penyebarluasan kegiatan pelatihan ini mengalami kendala teknis. Walaupun demikian, ada satu video yang masih dapat diselamatkan. Selain itu, karena tujuan dari pengabdian ini adalah pemberdayaan, maka setelah acara pelatihan ini, masih terus disediakan ruangan untuk melakukan evaluasi. Evaluasi dilakukan dengan pemberian testimoni peserta diselembar kertas.

Berdasarkan paparan di atas, metode dari pelatihan public speaking ini, menemukan sebuah model wacana kelas pedagogi public speaking. Berikut ini adalah gambar dari model tersebut:

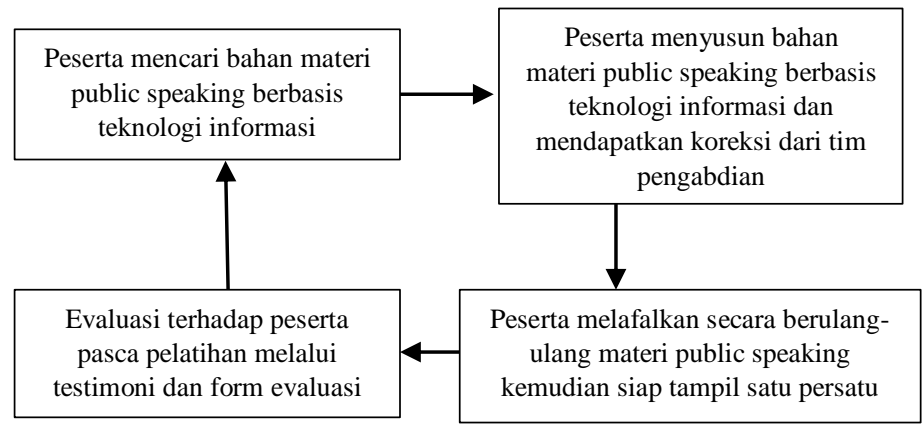

Gambar 6. Model Wacana Kelas Pedagogi Public Speaking

\section{SIMPULAN}

Kegiatan pengabdian ini diawali dengan melakukan analisis kebutuhan dari mitra kami, yaitu YSII untuk melakukan pelatihan public speaking berbasiskan teknologi informasi. Setelah melakukan sejumlah tahapan persiapan, dari mulai pendekatan dengan pengurus Yayasan, baik lewat pertemuan tatap muka dan bermedia sosial, akhirnya disepakati pelatihan public speaking berbasis teknologi informasi adalah bentuk pelatihan yang paling urgen untuk segera dilaksanakan.

Motode pelaksanaan pelatihan public speaking ini terdiri dari tiga tahap pelaksanaan. Adapun di dalam tahapan tersebut, menggunakan pengembangan 
Jurdimas (Jurnal Pengabdian Kepada Masyarakat) Royal

Vol. 2 No. 2, Juli 2019, hlm. 93 - 100

ISSN 2614-7912 (Print)

DOI: https://doi.org/10.33330/jurdimas.v2i2.275

ISSN 2622-3813 (Online)

Available online at https://jurnal.stmikroyal.ac.id/index.php/jurdimas

iptek, akan yang terpampang dalam gambar berikut ini:

Pengembangan Iptek/Model/Metode
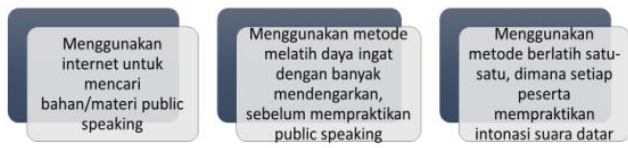

Gambar 7. Metode Pelaksanaan Pelatihan Berupa Pengembagan Iptek

Tiga Tahap

Berdasarkan gambar di atas, metode PKM ini berbasis teknologi informasi. Kehadiran teknologi informasi yang diawali dengan kemunculan internet, dewasa ini menjadi bagian yang tidak bisa dipiaahkan dari kehidupan sehari-hari. Bahkan untuk acara pelatihan yang bersifat pengabdian untuk kelompok ibu-ibu, pada hari ini juga mengunakan internet.

Dalam pelatihan ini, tahap pertama yang harus dilakukan peserta adalah bisa dan terbiasa mencari bahan materi public speaking dari internet. Kaum ibu zaman now, harus dapat mengunakan internet dan memanfaatkannya untuk aktivitas harian kaum ibu. Setelah para peserta bisa mencari bahan materi public speaking dari intenet, mereka diminta menentukan materi apa yang akan mereka sampaikan dalam public speaking, kemudian mereka mulai menyusun materi mereka sendiri dengan bahasa yang mudah dimengerti khalayaknya.

Para peserta diminta menuliskan materi public speaking mereka, lewat berbagai media, dari media laptop, handpohe, sampai media konvensial seperti kertas. Setelah selesai, maka dilakukan koreksi oleh pemateri atas bahan materi yang telah ditulis peserta. Setelah koreksi selesai, para peserta diminta untuk melafalkan materi public speaking dengan cara mengulang-ulang, sehingga semakin banyak mereka mendengar dan mengulang-ulang maka semakin hafal akan materi public speaking yang akan mereka sampaikan.

Setelah dirasakan cukup, para peserta secara satu persatu diminta tampil untuk melakukan simulasi. Namun simulasi kali ini adalah simulasi dengan teknik dasar, yaitu dengan suara datar terlebih dahulu. Hal ini dilakukan untuk menjadi emosi dan percaya diri peserta untuk tampil konstan terlebih dahulu.

Tujuan akhir dari pengabdian ini adalah para peserta tidak hanya sekadar bisa melakukan simulasi public speaking, namun juga praktik langsung disetiap acara YSII ataupun kegiatan lainnya di luar YSII. Pengalaman untuk praktik langsung ini, dievaluasi dengan cara peserta memberikan testimoninya pada selembar kertas dan diberikan juga form evaluasinya. Dengan demikian, kegiatan pegabdian ini mendapatkan masukan perbaikan untuk kegiatan pengabdian berikutnya.

Untuk pengabdian selanjutnya, tim pengabdian ini akan melaksanakan pemberdayaan lainnya yang masih berbasis teknologi informasi. Selain itu, metode dan model yang akan dipraktikan dalam pelatihan juga masih mengembangkan model wacana kelas pedagogi, agar dapat meneguhkan relasi hubungan model dan aplikasi praktis yang berbasis teknologi informasi. Berikut ini sesi foto yang dilakukan setelah acara berakhir: 


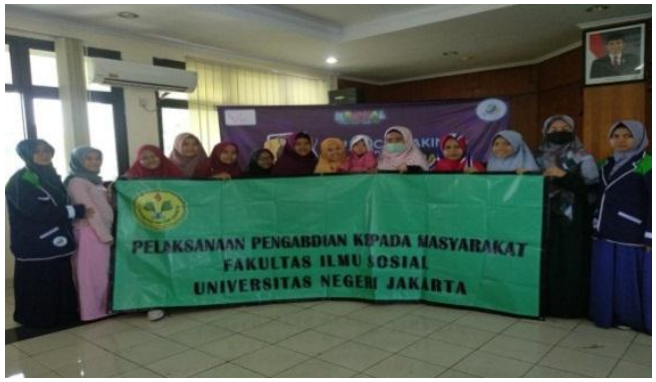

Gambar 8. Sesi Foto Bersama Peserta

\section{UCAPAN TERIMAKASIH}

Terimakasih saya ucapkan kepada kepala LPPM UNJ, Kelapa Korpus P2M UNJ, segenap staf LPPM UNJ, Dekan FIS UNJ, Pengurus YSII, Lurah Johar Baru, dan seluruh pihak yang telah membantu terlaksananya kegiatan pengabdian kepada masyarakat ini.

\section{DAFTAR PUSTAKA}

Damayanti, D. 2013. 1 Jam Mahir Public Speaking untuk Guru dan Dosen. Yogyakarta: Pinang Merah

Effendy, Onong Uchjana. 2003. Ilmu, Teori dan Filsafat Komunikasi. Cet ke-3, Bandung: Citra Aditya Bakti.

Hearne, Alexandra. 2014. Peran Media sosial di Pemilu Indonesia 2014. Ditulis 1 April 2014,

http://www.radioaustralia.net.au/indonesi an/2014-03-31/peran-sosial-mediadi-pemilu-indonesia-2014/1285446

Mulyana, Deddy. 2005. Nuansa-nuansa Komunikasi. Bandung: Remaja Rosdakarya

Noor, Faried Ma'ruf. 1983. Menuju Keluarga Sejahtera dan Bahagia. Bandung: Alma'arif
Putra, R. Masri Sareb. 2006. Teknik Menulis Berita dan Feature. Jakarta: Indeks.

Santoso, Edi dan Mite Setiansah. 2010. Teori Komunikasi. Yogyakarta: Graha Ilmu.

Tubss, L. Stewart dan Sylvia Moss. Human Communication. Bandung: Remaja rosda Karya

Yusuf, Pawit M. 2009. Ilmu Informasi Komunikasi dan Kepustakaan. Jakarta: bumi Aksara. 